\title{
APLIKASI MODEL KANO UNTUK ANALISIS KEBUTUHAN INFORMASI HARGA PADA E-TOURISM
}

\author{
Luh Gede Surya Kartika ${ }^{1}$, Komang Rinartha Yasa Negara ${ }^{2}$ \\ Suryakartika@uhnsuhriwa.ac.id, Universitas Hindu Negeri I Gusti Bagus Sugriwa Denpasar ${ }^{1}$ \\ komangrinartha@gmail.com, Institut Teknologi dan Bisnis STIKOM Bali ${ }^{2}$
}

\begin{abstract}
ABSTRAK
Informasi harga pada website e-toursim merupakan hal yang penting, sebab dapat digunakan sebagai referensi untuk pengambilan keputusan perjalanan wisata. Namun hingga saat ini belum ditemukan penelitian mengenai kebutuhan terhadap informasi harga pariwisata khususnya pada $e$-tourism. Konfirmasi mengenai kebutuhan informasi harga pada $e$-tourism akan mengarahkan pada pengaruh fungsionalitas tersebut terhadap kepuasan dan kekecewaan pengguna e-tourism. Penelitian ini menggunakan model Kano untuk menentukan kebutuhan fungsionalitas informasi harga pada e-tourism. Hasil yang diperoleh adalah fungsionalitas informasi harga merupakan kualitas penting yang sebaiknya dimiliki oleh website e-tourism. Kategori Kano untuk seluruh sub fungsionalitas informasi harga adalah bersifat "Must be". Artinya sub fungsionalitas informasi harga paket wisata, informasi harga aktivitas wisata, informasi harga souvenir, informasi harga tiket masuk, dan informasi harga transportasi pada e-tourism merupakan atribut fungsional yang dapat menurunkan kepuasan pengguna apabila tidak ditampilkan dengan baik. Namun, apabila informasi harga telah ditampilkan dengan baik, maka hal tersebut akan meningkatkan kepuasan pengguna secara signifikan karena responden mengangap bahwa informasi harga pada e-tourism memang sudah seharusnya ada dan kinerjanya sudah seharusnya baik.
\end{abstract}

Kata Kunci: e-tourism, informasi harga, Model Kano

\section{KANO MODEL APPLICATION TO ANALYZE PRICE INFORMATION REQUIREMENTS ON E-TOURISM}

\begin{abstract}
Price information on the e-toursim website is important, because it can be used as a reference for making travel decisions. However, until now there has been no research on the need for price information and especially on e-tourism. Confirmation of the need for price information on e-tourism will lead to the effect of this functionality on satisfaction and disappointment of e-tourism users. This study uses the Kano model to determine the functional needs of price information on e-tourism. The result obtained is that the functionality of price information is an important quality that must be possessed by an e-tourism website. The Kano category for all pricing information sub functionalities is "Must". This means that the sub-functionality of tour package price information, tourist activity price information, entrance ticket price information, and transportation price information on e-tourism are functional attributes that can reduce user satisfaction if they are not displayed properly. However, if the price information has been displayed properly, then it will increase user satisfaction significantly
\end{abstract}


because respondents think that price information on e-tourism should exist and the performance is good.

Keywords : e-tourism, price information, Kano Model

Copyright @2021. UHN IGB Sugriwa Denpasar. All Right Reserved

\section{PENDAHULUAN}

Salah satu pendapatan negara Indonesia adalah melalui industripariwisata. Namun, kondisi pandemi Covid19 telah membawa perubahan yang besar terhadap industri pariwisata di Indoneisia. Berdasarkan data pada website Badan Pusat Statistik (BPS) tahun 2021, pada bulan Desember 2020, Indonesia mengalami penurunan tajam pada jumlah kunjungan wisatawan dari mancanegara yaitu sebesar $88,08 \%$, apabila dibandingkan dengan data bulan yang sama pada tahun 2019. Jumlah kunjungan wisatawan mancanegara selama tahun 2020 ke Indonesia mencapai 4,02 juta kunjungan. Jumlah tersebut mengalami penurunan sebesar $75,03 \%$ dari jumlah kunjungan wisatawan mancanegara pada periode yang sama tahun 2019.

Dilihat dari tingkat hunian kamar, maka Tingkat Penghunian Kamar (TPK) hotel berbintang di Indonesia pada Desember 2020 mengalami penurunan sebesar 18,60 apabila dilakukan perbandingan dengan TPK bulan Desember
Kementerian Pariwisata dan Ekonomi Kreatif tahun 2020-2024 (Kementerian Pariwisata dan Ekonomi Kreatif RI, 2020) adalah meningkatnya kontribusi pariwisata dan ekonomi kreatif terhadap ketahanan ekonomi Indonesia dengan Produk Domestik Bruto sebesar $4.3 \%$ pada tahun 2022. Sedangkan jumlah pergerakan wisatawan nusantara (wisnus) ditargetkan antara 260 - 280 juta pergerakan pada tahun 2022.

Salah satu dari 17 strategi Kementerian Pariwisata dan Ekonomi kreatif (Kemenparekraf) dalam meningkatkan pariwisata di Indonesia adalah dilakukannya adopsi teknologi informasi dan komunikasi (TIK) secara efektif dan efisien. Pariwisata adalah industri dengan penggunaan informasi secara intensif. Perangkat elektronik memainkan peran penting dalam industri pariwisata. Perkembangan teknologi informasi dan komunikasi turut mengubah beberapa aspek pengelolaan pariwisata. Tren teknologi informasi dan komunikasi memungkinkan pemberian informasi

\section{undonesia (Perkembangan Jumlah Kunjungan Wisman 2018-2020 (Ribu Kunjungan)}

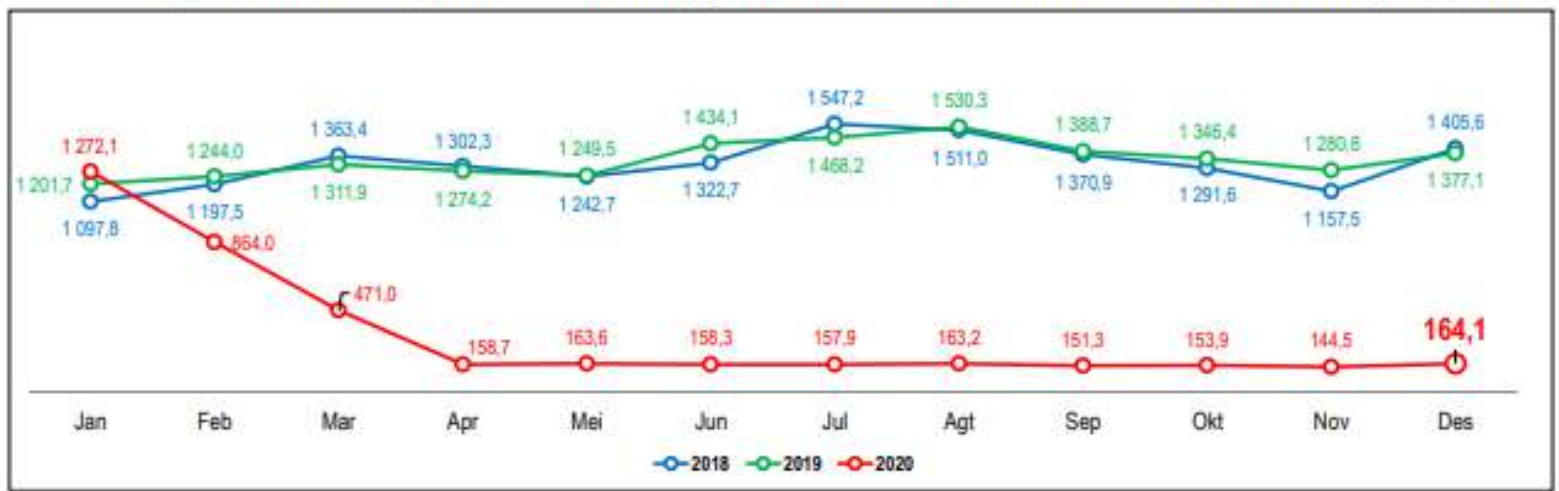

Gambar 1. Perkembangan Kunjungan Wisman di Indonesia, yang mengimplikasikan kondisi pariwisata di Indonesia

2019 (Gambar 1).

Perbaikan keadaan pariwisata di Indonesia tentu menjadi tantangan besar bagi seluruh negeri. Rencana strategi mengenai produk dan destinasi pariwisata dapat disampaikan pada wisatawan secara cepat dan tepat. Pertukaran informasi sangat penting pada setiap tahapan dalam 
pelayanan pariwisata. Akibatnya, teknologi informasi dan komunikasi telah menjadi fungsi yang hampir universal dari industri pariwisata. Kekuatan teknologi memungkinkan informasi untuk dikelola lebih efektif, dan didistribusikan ke seluruh dunia dengan sangat cepat.

Pemberian informasi mengenai pariwisata dapat dilakukan melalui berbagai media seperti e-tourism, website blog perjalanan wisata, media sosial, aplikasi pada smartphone, dan lain sebagainya (Kementerian Pariwisata dan Ekonomi Kreatif RI, 2020). Bahkan penetrasi dari media sosial yang tinggi menjadikannya sebagai media pemasaran pariwisata yang menjanjikan (Hamzah, 2013; Romadhan dkk., 2017). Media promosi wisata saat ini berkembang semakin pesat dengan mengadopsi beragam teknik pemasaran berbasis internet (Edoardo dkk., 2019). Penggunaan teknologi informasi dapat menyebabkan efisiensi dalam pemarasan wisata, serta tepat guna dalam menjangkau pangsa pasar yang lebih luas.

Teori marketing 4.0 mendorong perubahan dalam pemasaran produk pariwisata. Industri 4.0 memungkinkan proses produksi, pemasaran, distribusi, dan seluruh kegiatan bisnis lainnya menjadi lebih efektif dan efisien. Pendekatan Marketing 4.0 mengombinasikan interaksi dalam dan luar jaringan antara pengelola wisata dengan pelaku perjalanan/wisatawan. Penggunaan media dalam jaringan (online) dan luar jaringan (offline) dapat menceritakan kondisi suatu destinasi pariwisata secara terkini. Dengan penggunaan sarana dengan konektivitas yang tinggi, maka pengunjung atau calon wisatawan dapat melakukan penilaian, melihat kondisi sebenarnya, serta mengetahui pengalaman dari pengunjung lainnya, yang dapat memperkuat informasi yang disampaikan oleh pemerintah maupun informasi oleh pengelola dari objek wisata.

Salah satu bentuk penggunaan Teknologi informasi dalam dunia pariwisata adalah $e$-tourism. Terminologi $e$ tourism merupakan nama lain dari e- commerce. E-tourism dapat diartikan sebagai penggunaan teknologi informasi untuk meningkatkan hubungan stakeholder pariwisata, membantu pelaku usaha pada industri pariwisata sehingga dapat meningkatkan proses bisnis serta proses berbagi pengetahuan antara stakeholder pariwisata. E-tourism memanfaatkan beragam macam fungsionalitas dari teknologi informasi, yaitu: pengelolaan informasi pariwisata, pengelolaan pengguna, pembayaran elektronik, penggunaan jaringan komputer sebagai media transaksi jasa (Murtadho \& Shihab, 2011), serta penggunaan kecerdasan buatan untuk proses pemasaran, dan berbagai manfaat dari teknologi informasi.

Beberapa contoh e-tourism adalah https://gomandalika.com/,

https://infowisata.semarangkota.go.id/, https://visitbali.id/, atau https://www.tiket.com/

Instrumen penelian ini mengadopsi dari penelitan yang dilakukan oleh (Murtadho \& Shihab, 2011) mengenai analisis situs $e$ tourism Indonesia: studi terhadap persebaran geografis, pengklasifikasian situs serta pemanfaatan fungsi dan fitur. Namun penelitian ini hanya berfokus pada satu fungsionalitas dari total tujuh fungsionalitas utama yang diteliti oleh mereka. Penelitian ini berfokus pada fungsi utama advertising product/service with price, yaitu ketersediaan informasi harga pada e-tourism.

Fungsionalitas advertising product/service with price merupakan salah satu dari fungsi yang dijelaskan dalam Rita dan McCullough. Rekapitulasi data hasil dari penelitian oleh (Murtadho \& Shihab, 2011) adalah ditunjukkan oleh Tabel 1.

Tabel 1. Persentasi Situs yang

Mengandung Fungsionalitas Utama

\begin{tabular}{ll}
\hline \multirow{2}{*}{ Fungsionalitas Utama } & $\begin{array}{l}\text { Persentase situs } \\
\text { yang } \\
\text { mengandung } \\
\text { fungsionalitas } \\
\text { Utama }\end{array}$ \\
\hline General Publicity & $30 \%$ \\
\hline Advertising & $28 \%$ \\
\hline
\end{tabular}


Product/Service

\section{Advertising}

Product/Service with

Price

$12,96 \%$

Email Enquiry and

\begin{tabular}{ll} 
Interaction & $38,00 \%$ \\
\hline Email Booking & $10 \%$ \\
\hline Registration with ID & $22,83 \%$ \\
\hline On line Payment & $14,80 \%$ \\
\hline
\end{tabular}

Sumber: Agregat dari hasil penelitian oleh Murtadho \& Shihab (2011)

Berdasarkan Tabel 1, dapat diperhatikan bahwa fungsionalitas utama advertising product/service with price, merupakan salah satu fungsionalitas yang ketersediaannya cukup rendah yaitu $12,96 \%$ dari total 159 situs yang diteliti. Hal tersebut menunjukkan bahwa masih terdapat situs pariwisata di Indonesia yang belum tersebuka mengenai informasi harga. Hal tersebut menjadi alasan fungsionalitas harga menjadi fokus dari penelitian ini. yaitu melakukan konfirmasi mengenai kepuasan atau kekecewaan pengguna $e$ tourism terhadap ketersediaan atau ketiadaan fungsionalitas harga. Faktor Harga merupakan salah satu hal penting yang mempengaruhi kunjungan wisatawan (Dimyati \& Safitri, 2018; Rosida, 2018; Sirait, 2018). Namun hingga saat ini belum ditemukan penelitian mengenai kebutuhan terhadap informasi harga pariwisata khususnya pada e-tourism. Konfirmasi mengenai kebutuhan informasi harga pada e-tourism akan mengarahkan kita pada pengaruh fungsionalitas tersebut terhadap kepuasan dan kekecewaan pengguna $e$ tourism.

Berdasarkan latar belakang permasalahan, maka rumusan masalah dalam penelitian ini adalah "Apakah informasi harga berpengaruh terhadap kepuasan pengguna website e-tourism?".

\section{LITERATUR REVIEW}

\section{Kebutuhan TIK pada Pariwisata}

Organisasi pariwisata harus menyampaikan agregat informasi dengan menampilkan citra destinasi wisata yang menguntungkan ke pasar melalui jaringan dan saluran komunikasi internal dan eksternal . Karena perilaku konsumen yang berubah dengan cepat, distribusi informasi menjadi sangat penting dalam persaingan global (Tanaka, 2011). Informasi destinasi tidak boleh statis, harus diperbarui sesuai permintaan dan ketersediaan pasar. Aliran informasi dan komunikasi tidak hanya membantu wisatawan untuk mendapatkan gambaran pasar tentang tren perjalanan wisatawan, pemanfaatan sumber daya, dan data statistik, tetapi juga untuk meningkatkan aliran komunikasi dengan konsumen.

Saat ini perubahan terbesar dalam perilaku konsumen adalah bagaimana mencari informasi. Internet banyak digunakan untuk mencari informasi dan perbandingan produk, yang menghindari risiko ketidaksesuaian antara kualitas layanan dan informasi. Informasi tradisional akan digantikan oleh informasi elektronik. Seberapa besar destinasi menggunakan sistem informasi elektronik dapat menjadi faktor untuk mengukur kompetensi di bidang pariwisata (Tanaka, 2011).

Perusahaan dapat menemukan peluang bisnis untuk menjangkau pasar potensial melalui internet. Internet digunakan tidak hanya sebagai media pemasaran, tetapi juga sebagai sarana komunikasi antara penyedia jasa dan pelanggan. Menjaga situs atau website yang efektif telah menjadi elemen kunci dalam memperkuat hubungan dengan wisatawan. Menurut Philip Kotler dalam (Tanaka, 2011) tiga keuntungan penting mengapa konsumen beralih ke e-business, yaitu:

1) Meningkatkan efisiensi: teknologi tersebut dapat digunakan pada waktu dan tempat sesuai dengan kebutuhan penggunanya.

2) Informasi yang bervariasi: memungkinkan untuk memperoleh informasi tentang perjalanan dan tujuannya

3) Mengurangi biaya: memungkinkan untuk membandingkan harga dan mendapatkan harga yang lebih rendah 
Oleh karena itu, bagi para penyedia jasa wisata, penggunaan teknologi informasi atau website menjadi salah satu sarana pemasaran yang paling penting dan nyaman. Teknologi dapat digunakan untuk memperkenalkan konten, keunikan, dan diferensiasi produk wisata.

\section{Metode Kano}

Model Kano merupkanan model yang dikembangkan pada tahun 1984 oleh Noriaki Kano. Model Kano dapat digunkan untuk memberikan kategorisasi atribut dari produk atau jasa berdasarkan kemampuannya untuk memenuhi kebutuhan pelanggan (Safi'i, 2018; Sahfitri \& Yulianingsih, 2015). Atribut tersebut dapat dibedakan menjadi beberapa kategori yaitu:

1) Atribut dengan kategori must be atau basic needs, yaitu atribut yang dapat menurunkan kepuasan pengguna apabila kinerja atribut tersebut rendah. Namun, apabila kinerja fungsionalitas tersebut tinggi, tidak akan meningkatkan kepuasan pengguna secara signifikan karena fungsionalitas tersebut dianggap memang sudah seharusnya ada dan kinerjanya baik.

2) Atribut dengan kategori one dimensional atau performance needs, yaitu fungsionalitas yang apabila memiliki kinerja yang tinggi, maka akan dapat meningkatkan kepuasan pengguna.

3) Atribut dengan kategori atractive atau excitement needs, merupakan fungsionalitas yang akan menyebabkan peningkatan kepuasan pelanggan apabila kinerja fungsionalitas tersebut juga tinggi. Namun, apabila terjadi penurunan kinerja dari fungsionalitas tersebut, maka tidak akan menyebabkan penurunan tingkat kepuasan (Nofirza \& Indrayani, 2011).

4) Fungsionalitas dengan kategori Indifferent, yaitu pengguna sistem tidak memperdulikan adanya fungsionalitas yang ditawarkan sehingga ada atau tidaknya fungsionalitas tersebut tidak akan berpengaruh terhadap kenaikan atau penurunan tingkat kepuasan pengguna system.

\section{METODE}

Langkah-langkah pengukuran dengan menggunakan Model Kano adalah sebagai berikut:

1) Identifikasi fungsionalitas dengan melihat hasil penelitian pendahulu

2) Dilakukan penyusunan kuesioner sebagai digunakan untuk menentukan tanggapan pengguna $e$-toursim.

3) Langkah-langkah kategorisasi fungsionalitas berdasarkan model Kano.

a) Menentukan kategori fungsionalitas tiap responden berdasarkan Tabel 2.

Tabel 2. Pemetaan Kategori Kano

\begin{tabular}{|c|c|c|c|c|c|c|}
\hline \multirow{2}{*}{\multicolumn{2}{|c|}{$\begin{array}{l}\text { Kebutuhan } \\
\text { Pengguna } e \text { - } \\
\text { tourism }\end{array}$}} & \multicolumn{3}{|c|}{$\begin{array}{l}\text { Disfungsional } \\
\text { negative) }\end{array}$} & \multicolumn{2}{|c|}{ (Pernyataan } \\
\hline & & 1 & 2 & 3 & 4 & 5 \\
\hline \multirow{5}{*}{ 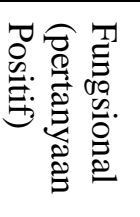 } & 1 & Q & A & A & A & $\mathrm{O}$ \\
\hline & 2 & $\mathrm{R}$ & I & I & $\mathrm{I}$ & $\mathrm{M}$ \\
\hline & 3 & $\mathrm{R}$ & I & I & I & $\mathrm{M}$ \\
\hline & 4 & $\mathrm{R}$ & I & $\mathrm{I}$ & I & $\mathrm{M}$ \\
\hline & 5 & $\mathrm{R}$ & $\mathrm{R}$ & $\mathrm{R}$ & $\mathrm{R}$ & $\mathrm{Q}$ \\
\hline \multicolumn{7}{|c|}{ Sumber: (Nofirza \& Indrayani, 2011) } \\
\hline \multicolumn{7}{|c|}{ Keterangan : } \\
\hline Q & & \\
\hline $\mathrm{R}$ & & \multicolumn{5}{|c|}{ = Reverse (Kemunduran), } \\
\hline A & & \multicolumn{5}{|c|}{$=$ Attractive (Menarik), } \\
\hline \multicolumn{2}{|c|}{$\mathrm{I}=$ Indefferent (Netral), } & \multicolumn{5}{|c|}{$=$ Indefferent $($ Netral $)$, } \\
\hline \multirow{2}{*}{\multicolumn{7}{|c|}{$\begin{array}{l}\mathrm{O}=\text { One } \\
\text { Ukuran) } \mathrm{M}\end{array}$}} \\
\hline & & & & & & \\
\hline \multicolumn{7}{|c|}{ (Keharusan). } \\
\hline \multicolumn{7}{|c|}{ 1. Suka } \\
\hline \multicolumn{7}{|c|}{ 2. Sudah seharusnya } \\
\hline \multicolumn{7}{|c|}{ 3. Netral } \\
\hline \multicolumn{7}{|c|}{ 4. Tidak masalah } \\
\hline \multicolumn{7}{|c|}{ 5. Tidak Suka } \\
\hline
\end{tabular}

b) Menentukan kategori model Kano pada tiap fungsionalitas dengan menggunakan Blauth's Formula yaitu:

Jika jumlah nilai $(\mathrm{O}+\mathrm{A}+\mathrm{M})>$ jumlah nilai $(\mathrm{I}+\mathrm{R}+\mathrm{Q})$ maka grade diperoleh nilai paling maksimum dari $(\mathrm{O}, \mathrm{A}$, atau $\mathrm{M})$, 
Jika jumlah nilai $(\mathrm{O}+\mathrm{A}+\mathrm{M})<$ jumlah nilai $(\mathrm{I}+\mathrm{R}+\mathrm{Q})$ maka grade diperoleh yang paling maksimum dari (I,R, atau Q).

Jika jumlah nilai $(\mathrm{O}+\mathrm{A}+\mathrm{M})=$ jumlah nilai $(\mathrm{I}+\mathrm{R}+\mathrm{Q})$ maka grade diperoleh yang paling maksimum diantara semua kategori kano yaitu (O,A,M dan I,R, dan Q).

4) Menghitung nilai koefisien kepuasan dan kekecewaan. Koefisien kepuasan memberikan indikasi mengenai tingkat kenaikan kepuasan pelanggan jika kita menyediakan fungsionalitasnya (A dan O). Koefisien kekecewaan memberikan indikasi mengenai tingkat penurunan kepuasan pelanggan jika kita tidak menyediakan fiturnya ( $\mathrm{O}$ dan $\mathrm{M})$. Adapun formula untuk menghitung koefisien kepuasan dan kekecewaan adalah sebagai berikut:

$$
\begin{gathered}
\text { Koefisien Kepuasan }=\frac{A+O}{A+O+M+I} \\
\text { Koefisien kekecewaan }=\frac{A+M}{A+O+M+I}
\end{gathered}
$$

Variabel dalam penelitian ini adalah fungsionalitas informasi harga pada situs $e$ tourism. Fungsionalitas ini diadopsi dari penelitian yang dilakukan oleh Murtadho \& Shihab (2011). Sub fungsionalitas yang digunakan adalah sebegai berikut:

1) Informasi Harga Paket Wisata

2) Informasi Harga Aktivitas Wisata

3) Informasi Harga Souvenir

4) Informasi Harga Tiket masuk

5) Informasi Harga Transportasi

Table 3 menunjukkan instrumen atau alat penelitian yang digunakan untuk pengumpulan data. Instrumen tersebut sesuai dengan Model Kano, dimana setiap sub-fungsionalitas representasikan dalam dua pernyataan, yang mengandung unsur "terdapat" (fungsional) atau pernyataan positif dan "tidak terdapat" (disfungsional) atau pernyataan negative. Instrumen tersebut selanjutnya diubah menjadi bentuk kuesioner dengan memanfaatkan aplikasi Google Forms.

\begin{tabular}{|c|c|}
\hline Kode & rnyataan Kano \\
\hline & $\begin{array}{l}\text { Pada situs e-tourism terdapat } \\
\text { informasi mengenai harga paket } \\
\text { pariwisata }\end{array}$ \\
\hline 01 & $\begin{array}{l}\text { Pada situs e-tourism tidak } \\
\text { terdapat informasi mengenai harga } \\
\text { paket pariwisata }\end{array}$ \\
\hline 02 & $\begin{array}{lr}\text { Pada situs e-tourism } & \text { terdapat } \\
\text { informasi/fungsionalitas } & \text { harga } \\
\text { aktivitas pariwisata } & \end{array}$ \\
\hline 02 & $\begin{array}{l}\text { Pada situs e-tourism tidak } \\
\text { terdapat informasi mengenai harga } \\
\text { aktivitas pariwisata }\end{array}$ \\
\hline 03 & $\begin{array}{lr}\text { Pada situs e-tourism } & \text { terdapat } \\
\text { fungsionalitas/informasi } & \text { harga } \\
\text { souvernir } & \\
\end{array}$ \\
\hline 03 & $\begin{array}{l}\text { Pada situs e-tourism tidak } \\
\text { terdapat informasi/fungsionalitas } \\
\text { harga souvernir }\end{array}$ \\
\hline 04 & $\begin{array}{l}\text { Pada situs e-tourism terdapat } \\
\text { informasi/fungsionalitas harga tiket } \\
\text { masuk }\end{array}$ \\
\hline 04 & $\begin{array}{l}\text { Pada situs e-tourism tidak } \\
\text { terdapat informasi/fungsionalitas } \\
\text { harga tiket masuk }\end{array}$ \\
\hline 05 & 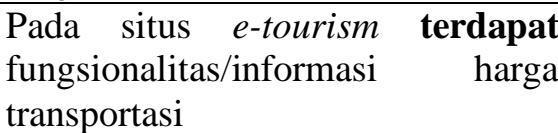 \\
\hline 05 & $\begin{array}{ll}\text { Pada situs } & \text { e-tourism } \\
\text { terdapat } & \text { informasi } \\
\text { transportasi } & \end{array}$ \\
\hline
\end{tabular}

Tabel 3. Instrumen Penelitian

Teknik sampling yang digunakan adalah sampling kuota. Teknik sampling kuota merupakan teknik penentuan sampel dari populasi yang mempunyai ciri-ciri tertentu sampai sejumlah yang diinginkan dalam penelitian. Pada proses sampling, penelian ini dimulai dengan membuat penjabaran tentang karakteristik yang dinginkan dari populasi selanjutnya ditentukan sampel yang memenuhi ciri-ciri dari populasi tersebut.

Karakteristik responden tersebut adalah sebagai berikut: 
1. Responden merupakan seseorang yang berusia lebih atau sama dengan 15 tahun, dengan asumsi bahwa usia tersebut sudah mampu mengambil keputusan atau memberikan rekomendasi mengenai perjalanan wisata

2. Responden mampu menggunakan website atau internet dengan baik dan mandiri

3. Responden dapat memiliki beragam matapencaharian dan dapat berasal dari berbagai daerah di Indonesia.

Skala jawaban pada kuesioner yang digunakan adalah sesuai dengan metode Kano, yaitu ditunjukkan oleh Tabel 4.

Tabel 4. Skala Jawaban pada Instrumen Penelitian

\begin{tabular}{lll}
\hline \multirow{2}{*}{ Skor } & \multicolumn{2}{c}{ Jawaban } \\
\cline { 2 - 3 } & Fungsional & Disfungsional \\
\hline 1 & Suka & Suka \\
\hline 2 & $\begin{array}{l}\text { Sudah } \\
\text { seharusnya }\end{array}$ & $\begin{array}{l}\text { Sudah } \\
\text { seharusnya }\end{array}$ \\
\hline 3 & Netral & Netral \\
\hline 5 & Tidak masalah & Tidak masalah \\
\hline Ketera- & Tidak Suka & Tidak Suka \\
ngan & $\begin{array}{l}\text { pernyataan } \\
\text { dengan unsur } \\
\text { "terdapat" }\end{array}$ & $\begin{array}{l}\text { Untuk } \\
\text { pernyataan } \\
\text { dengan unsur } \\
\end{array}$ \\
\hline
\end{tabular}

\section{HASIL DAN PEMBAHASAN}

Pengumpulan data dilakukan pada tanggal 14-30 Mei 2021, dengan menggunakan Google Forms. Penyebaran kuesioner dilakukan melalui kelompokkelompok pada aplikasi Whatsapp serta melalui kontak pribadi. Data yang terkumpul adalah sebesar 167. Selanjutnya, dilakukan pengujian reliabilitas untuk melihat ketahan atau konsistensi dari instrument pengumpulan data. Hasil pengujian reliabilitas adalah menggunakan Cronbach's Alpha. Apabila nilai Cronbach's Alpha lebih dari 0.5, maka instrumen dianggap dapat digunakan untuk mengumpulkan data. Hasil pengujian reliabilitas ditunjukkan oleh Tabel 5.

Tabel 5. Hasil pengujian reliabilitas

\begin{tabular}{lll}
\hline & $\begin{array}{l}\text { Cronbach' } \\
\text { S Alpha }\end{array}$ & Intepretasi \\
\hline Fungsional & 0.71 & $\begin{array}{l}\text { reliabilitas } \\
\text { cukup }\end{array}$ \\
\hline Disfungsional & 0.756 & $\begin{array}{l}\text { reliabilitas } \\
\text { cukup }\end{array}$ \\
\hline
\end{tabular}

Tabel 5 menujukkan hasil pengujian reliabilitas. Nilai Cronbach's Alpha $>0.7$ sehingga dapat dintepretasikan sebagai reliabilitas cukup, artinya instrumen yang digunakan memiliki konsistensi yang cukup apabila digunakan untuk pengumpulan data kembali.

Karakteristik atau identitas responden penelitian ditunjukkan oleh Gambar 2. Sebagian besar responden yaitu sebanyak $61,9 \%$ berusia $15-20$ tahun, dan responden tertua berusia 41-50 tahun.

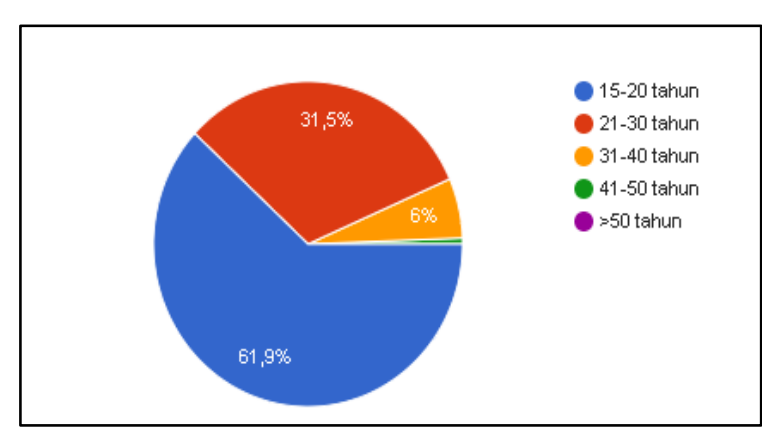

Gambar 2. Identitas Responden Berdasarkan Usia

Selanjutnya dari 167 data yang terkumpul dilakukan kategorisasi Kano yang ditunjukkan dalam Tabel 6 dan divisualisasikan dalam Gambar 3. Selanjunya, dilakukan perhitungan Blauth's formula untuk menentukan grade dari sub fungsional tersebut. Hal tersebut ditunjukkan pada Tabel 7. Berdasarkan hasil perhitungan diperoleh bahwa grade dari seluruh fungsionalitas adalah Must be (M). Artinya sub fungsionalitas Informasi Harga Paket Wisata, Informasi Harga 
Aktivitas Wisata, Informasi Harga sudah seharusnya ada dan kinerjanya sudah

Souvenir, seharusnya baik. Hasil penelitian ini mengkonfirmasi penelitian dari Dimyati \&

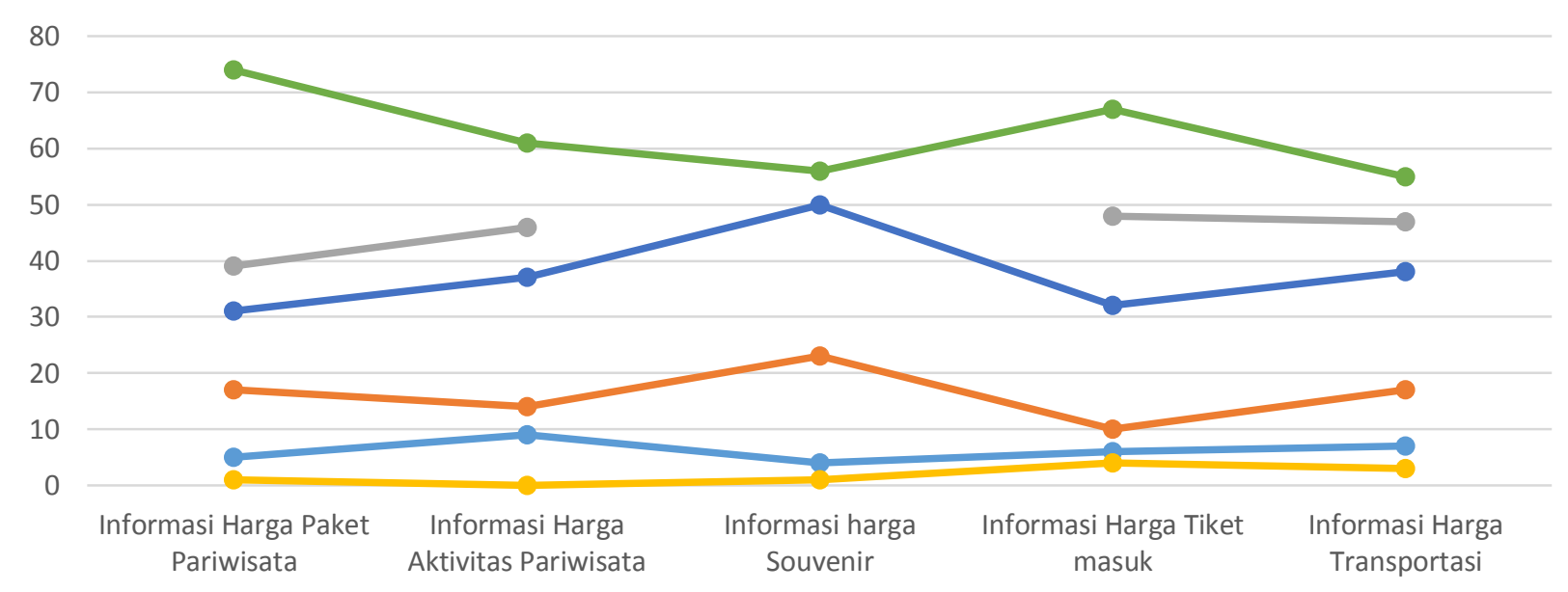

Tabel 6. Rekapitulasi Kategori Kano dari Sub Fungsionalitas

\begin{tabular}{lccccccc}
\hline & \multicolumn{7}{c}{ Kategori Kano } \\
\cline { 2 - 7 } $\begin{array}{c}\text { Fungsio } \\
\text { nalitas }\end{array}$ & $\mathbf{Q}$ & $\mathbf{A}$ & $\mathbf{O}$ & $\mathbf{R}$ & $\mathbf{I}$ & $\mathbf{M}$ \\
\hline $\begin{array}{l}\text { Harga } \\
\text { Paket }\end{array}$ & 5 & 17 & 39 & 1 & 31 & $\mathbf{7 4}$ \\
\hline $\begin{array}{l}\text { Harga } \\
\text { Aktivitas }\end{array}$ & 9 & 14 & 46 & 0 & 37 & $\mathbf{6 1}$ \\
\hline $\begin{array}{l}\text { Harga } \\
\text { Souvenir }\end{array}$ & 4 & 23 & 33 & 1 & 50 & $\mathbf{5 6}$ \\
\hline $\begin{array}{l}\text { Harga } \\
\text { Tiket } \\
\text { masuk }\end{array}$ & 6 & 10 & 48 & 4 & 32 & $\mathbf{6 7}$ \\
\hline $\begin{array}{l}\text { Harga } \\
\text { Transpor } \\
\text { tasi }\end{array}$ & 7 & 17 & 47 & 3 & 38 & $\mathbf{5 5}$ \\
\hline
\end{tabular}

Informasi harga Tiket masuk, dan Informasi Harga Transportasi pada $e$ tourism merupakan atribut fungsional yang dapat menurunkan kepuasan pengguna apabila informasi harga tidak ditampilkan dengan baik. Informasi harga diharapkan akurat dan sesuai dengan kondisi kenyataan di lapangan. Namun, apabila informasi harga telah ditampilkan dengan baik, maka hal tersebut tidak akan meningkatkan kepuasan pengguna secara signifikan karena responden mengangap bahwa informasi harga pada e-tourism memang
Safitri (2018); Rosida (2018); dan Sirait (2016).

Tabel 7. Hasil Perhitungan Grade dengan menggunakan Blauth's Formula

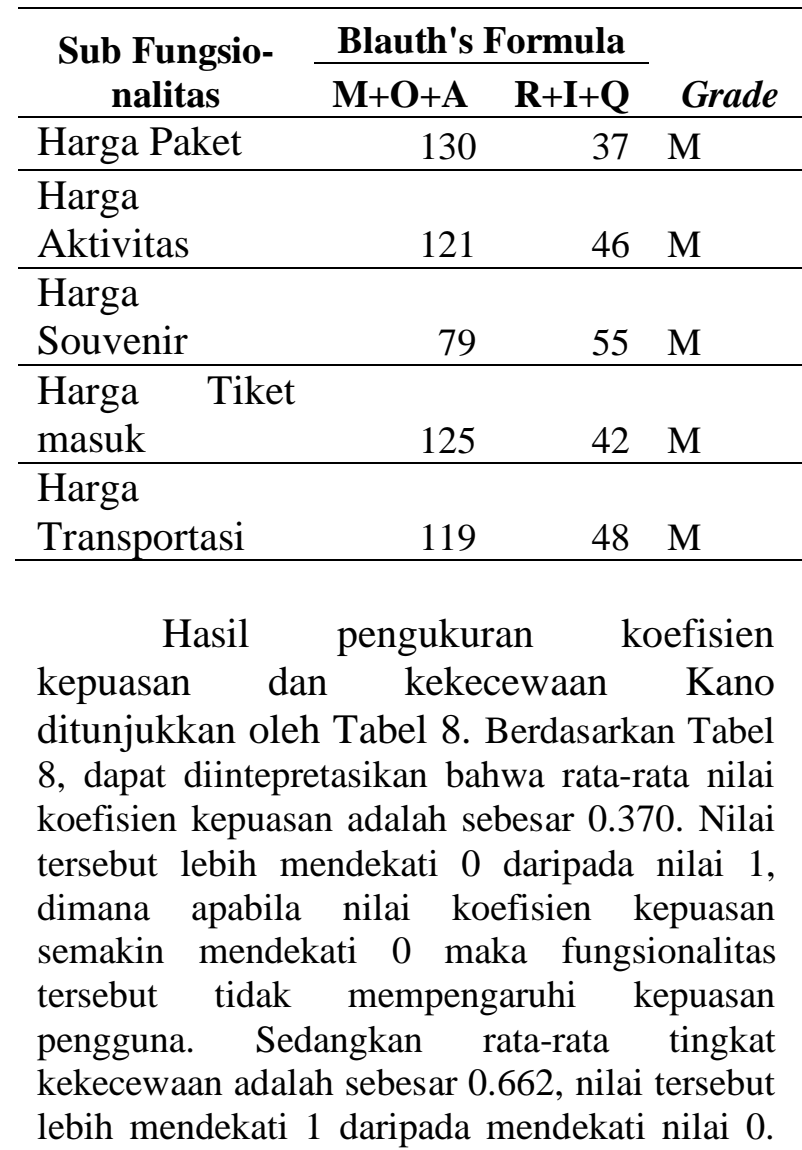


Apabila nilai koefisien kekecewaan mendekati 0 maka fungsionalitas tersebut tidak menyebabkan kekecewaan.

Tabel 8. Besaran koefisien Kepuasan dan Kekecewaan Pengguna

\begin{tabular}{|c|c|c|}
\hline Fungsionalitas & $\begin{array}{l}\text { Koefisien } \\
\text { Kepuasan }\end{array}$ & $\begin{array}{l}\text { Koefisien } \\
\text { Kekecewaan }\end{array}$ \\
\hline Harga Paket & 0,348 & 0,702 \\
\hline $\begin{array}{l}\text { Harga } \\
\text { Aktivitas }\end{array}$ & 0,380 & 0,677 \\
\hline $\begin{array}{l}\text { Harga } \\
\text { Souvenir }\end{array}$ & 0,346 & 0,549 \\
\hline $\begin{array}{ll}\text { Harga } & \text { Tiket } \\
\text { masuk } & \\
\end{array}$ & 0,369 & 0,732 \\
\hline $\begin{array}{l}\text { Harga } \\
\text { Transportasi }\end{array}$ & 0,408 & 0,650 \\
\hline Rata-rata & 0,370 & 0,662 \\
\hline
\end{tabular}

Fungsionalitas dengan nilai koefisien kepuasan tertinggi adalah informasi Harga transportasi yaitu sebesar 0,408, hal ini menujukkan bahwa informasi harga transportasi yang paling memungkinkan untuk memepengaruhi kepuasan walaupun tidak signifikan.

Fungsionalitas yang memiliki nilai koefisien kekecewaan tertinggi adalah informasi harga paket, yaitu sebesar 0.702 . Dalam koefisien kekecewaan, apabila nilainya semakin mendekati nilai satu, maka variabel tersebut semakin mempengaruhi tingkat kekecewaan pengguna. Hal ini menunjukkan bahwa apabila informasi harga paket wisata tidak ditampilkan dengan baik, maka akan menyebabkan kekecewaan pengguna yang signifikan.

Secara umum, hasil analisis menunjukkan bahwa, fungsionalitas informasi harga dianggap merupakan seseuatu yang sudah seharusnya ada dalam e-tourism, sehingga keberadaannya dapat dianggap sebagai "take if for granted", dan pengguna menerima begitu saja keberadaan fungsionalitas tersebut. Untuk mengetahui besarnya pengaruh dari kualitas informasi harga pada situs/website e-tourism terhadap hal-hal dari perilaku pengguna memerlukan penelitian lebih lanjut.

Secara umum, informasi harga merupakan salah satu hal yang menjadi bahan pertimbangan bagi calon wisatawan untuk merencanakan dan mengambil keputusan mengenai kegiatan wisata mereka. Selain itu, pengguna atau calon wisatawan dapat menggunakan informasi harga pariwisata untuk melakukan perbandingan produk/jasa pariwisata yang ditawarkan pada masingmasing situs. Kejelasan informasi harga juga dapat menumbuhkan kredibilitas website dan meningkatkan kepercayaan dari pengguna $e$-tourism.

Pada e-tourism produk wisata di Indonesia, umumnya situs e-tourism yang dikelola oleh lembaga industri perjalanan memuat informasi harga. Namun hasil penelusuran pada beberapa e-toursim yang dimiliki oleh pemerintah RI tidak mengandung fungsionalitas informasi harga. Hasil penelusuran pada situs go https://gomandalika.com/profil// yang hadir sebagai referensi utama informasi pariwisata Lombok Tengah, telah memasang iklan destinasi wisata kulinari di Lombok Tengah, namun tidak mencantumkan informasi harga dari produk wisata tersebut. Demikian pula dengan situs pariwisata daerah lain, seperti https://infowisata.semarangkota.go.id/ atau https://visitbali.id/. Diperlukan penelurusuran lebih lanjut mengenai tujuan dari situs-situs pariwisata tersebut, apabila tujuannya adalah menjadi e-tourism, maka penambahan fungsionalitas informasi harga dibutuhkan pada situs-situs tersebut.

\section{SIMPULAN}

Berdasarkan analisis hasil, maka kesimpulan yang dapat diperoleh adalah fungsionalitas informasi harga merupakan kualitas penting yang dimiliki oleh website e-tourism. Kategori Kano untuk seluruh sub fungsionalitas informasi harga adalah Must be (M). Artinya sub fungsionalitas informasi harga paket wisata, informasi harga aktivitas wisata, informasi harga souvenir, informasi harga tiket masuk, dan informasi harga transportasi pada e-tourism merupakan atribut fungsional yang dapat menurunkan kepuasan pengguna apabila tidak ditampilkan dengan baik. Namun, apabila informasi harga telah ditampilkan dengan baik, maka hal tersebut tidak akan meningkatkan kepuasan pengguna secara signifikan karena responden mengangap bahwa informasi harga pada e-tourism memang sudah seharusnya ada dan kinerjanya sudah seharusnya baik. 
Kategorisasi yang dihasilkan dikonfirmasi oleh hasil pengukuran ratarata koefisien kepuasan dan kekecewaan pengguna. Secara umum, fungsionalitas informasi harga dianggap merupakan seseuatu yang sudah seharusnya ada dalam e-tourism, sehingga keberadaannya dapat dianggap sebagai "take if for granted", dan pengguna menerima begitu saja keberadaan fungsionalitas tersebut.

\section{REFERENSI}

Dimyati, A., \& Safitri, W. (2018). Pengaruh kualitas pelayanan, harga, dan daya tarik wisata terhadap minat berkunjung ulang (. Jurnal Manajemen Fakultas Ekonomi Dan Ilmu Sosial Universitas Pelita Bangsa.

Edoardo, I., Zakaria, L., \& Sukirno. (2019). Teknologi Komunikasi Informasi dan Dekonstruksi Tren Perjalanan Wisata. Journal of Tourism and Creativity, 3(2), 179-192.

Hamzah, Y. I. (2013). Potensi Media Sosial Sebagai Sarana Promosi Interaktif Bagi Pariwisata Indonesia. 8(3), 1-9.

Kementerian Pariwisata dan Ekonomi Kreatif RI. (2020). Rencana Strategis.

Murtadho, A., \& Shihab, M. R. (2011). Analisis Situs E-Tourism Indonesia : Studi Terhadap Persebaran Geografis , Pengklasifikasian Situs Serta Pemanfaatan Fungsi Dan Fitur. Journal of Information Systems, 7(1), 13-25.

https://doi.org/10.21609/jsi.v7i1.290

Nofirza, \& Indrayani, K. (2011). Aplikasi

Metode Kano Dalam Analisis

Indikator Kualitas Pelayanan Di

Rumah Sakit Arifin Ahmad Pekanbaru. Jurnal Sains, Teknologi Dan Industri, 9(1), 1-8.

Romadhan, M. I., Sri, D., \& Rusmana, A. (2017). Potensi Media Sosial Sebagai Sarana Media Promosi Pariwisata Berbasis Partisipasi Masyarakat. Prosiding Seminar Dan Call For Paper Fakultas Ilmu Sosial Dan Ilmu Politik Universitas Muhammadiyah Sidoarjo, 85-90.
Rosida, F. (2018). Pengaruh Harga dan Fasilitas Terhadap Kunjungan Wisata di Pantai Air Bangis Kabupaten Pasaman Barat. Fakultas Ekonomi dan Bisnis Islam, Universitas Islam Negeri Sumatera Utara.

Safi'i, I. (2018). Klasifikasi Atribut Pelayanan Mobile Banking dengan Kano Model Berdasarkan Dimensi EServqual. Jurnal Sistem Dan Manajemen Industri, 2(2), 77-84.

Sahfitri, V., \& Yulianingsih, E. (2015). Kualitas layanan sistem informasi akademik menggunakan metode kano. Jurnal Ilmiah MATRIK, 2(3), 151162.

Sirait, H. (2016). Pengaruh Harga dan Fasilitas Terhadap Keputusan Berkunjung Wisatawan di Objek Wisata Bukit Gibeon Kecamatan Ajibata Kabupaten Toba Samosir.

Tanaka, A. (2011). Comparative Study of etourism between Austria and Hokkaido ( Japan ). Modul University Vienna. https://www.modul.ac.at/uploads/files/ Theses/Master/Thesis-2011-TanakaAkiko.pdf

\section{BIODATA PENULIS}

Penulis merupakan seorang dosen pada Universitas Hindu Negeri I Gusti Bagus Sugriwa Denpasar. Saat artikel ini dibuat, penulis sedang berstatus sebagai CPNS. Orchid ID penulis adalah https://orcid.org/0000-0001-9895-1418 dengan Sinta ID 6125663 